\title{
How children "add" or "restrict" entities and temporal spans in narrations: evidence from Italian and English native children
}

\author{
Patrizia Giuliano (Napoli)
}

\begin{abstract}
This work focuses on the acquisition of restrictive and (temporal and non temporal) additive means by Italian and English native children, especially including scope particles, together with children's progressing ability to build textual cohesion in a narrative text. In particular, the author tries to identify the age at which additive and restrictive means appear and the functions they carry out in discourse organization of very young subjects, as well as the cognitive operations the latter can use. Thanks to the consideration of two different languages, this work also explores the possible language-specific strategies exploited by the two groups of children.

Part of the results can be read as age cognitive restrictions independent of the L1 of the child. Additive means appear from the age of four on but with some differences according to the types of quantification solicited, namely the quantification of entities and that of time spans: the 4-year-olds clearly have less problems in quantifying entities rather than time spans. In comparison with adult reference groups, Italian and English L1 children of any group exploit additive temporal means less frequently than means quantifying entities; the quantification of entities involving a negation shows up from the age of seven. From a cognitive viewpoint, the precocious emergence of entity contrasts by additive means is in agreement with what Givón (1995) maintains with respect to nominal referents (they are perceptually and cognitively more salient, they are acquired early in ontogeny and evolve early in phylogeny, they are culturally central entities etc.). Concerning negative particles, their later appearance is in agreement with some studies about negation showing the more problematic processing of negative structures by children with respect to the positive ones (cf. Giuliano 2004).

Some other strategies identified in children's retellings are, conversely, to be interpreted as language-specific. The more frequent problems that Italian children have with the concept of iteration with respect to English L1 children could be due to the polyfunctional semantics of the Italian particles ancora ('more, again, still') and sempre ('always, again, still'); the late appearance of also in English L2 children's data, an internal positioning particle, is probably caused by the fact that English has an external, perceptually more salient particle, namely too, whose semantics is equal to that of also.
\end{abstract}




\section{$1 \quad$ Introduction}

The role of additive and restrictive means in textual cohesion has attracted the attention of several scientists in the last twenty years, but generally with respect to adult native speakers or adult learners of some Romance and Germanic languages (cf., for example, Andorno 2005; Benazzo 2003; Dimroth 2002; Watorek/Dimroth 2005). The role of these same items in the acquisition of an L1 by children is less studied (cf., among other studies, Benazzo et al. 2004; Dimroth 2009; Giuliano 2012a/b), although they are crucial means for textual cohesion and can occur in any type of text.

In the present paper I shall discuss the acquisition of restrictive and (temporal and non temporal) additive means by Italian and English native children, especially including scope particles, together with the child's progressing ability of building textual cohesion in a narrative text. In particular, I shall try to identify the age at which additive and restrictive means appear and the functions they carry out in discourse organization of very young subjects, as well as the cognitive operations the latter have resort to. Furthermore, thanks to the consideration of two different languages, it will be possible to explore the possible language-specific strategies exploited by the two groups of children.

\section{The informants and the task}

The informants are Italian and English native children of 4, 7 and 10 years and their narrations will be compared to those of two adult (Italian and English native) reference groups.

\begin{tabular}{|l|l|l|l|l|l|}
\hline \multicolumn{5}{|l|}{ English native groups } & \multicolumn{4}{l|}{ Italian native groups } \\
\hline Age & N. Interviews & Place of Birth & Age & N. Interviews & Place of Birth \\
\hline 4 & 10 & USA (9); Australia (1) & 4 & 20 & Naples (19); Rome (1) \\
\hline 7 & 10 & USA (7); UK (3) & 7 & 20 & Naples (19); Milan (1) \\
\hline 10 & 10 & UK & 10 & 20 & Naples (17); Milan (3) \\
\hline $\begin{array}{l}\text { Adults } \\
(23-31)\end{array}$ & 20 & $\begin{array}{l}\text { USA (14); UK (5); } \\
\text { Ireland (1) }\end{array}$ & $\begin{array}{l}\text { Adults } \\
(22-35)\end{array}$ & 20 & Naples \\
\hline
\end{tabular}

Table 1: The informants.

The type of texts analysed are narrations collected using the video clip The Finite Story created by Dimroth (2006). The video clip The Finite Story is about three men, Mr. Blue, Mr. Green and Mr. Red, living in three different flats of the same building, which one night catches fire. It is subdivided into several segments - the content of which is illustrated in Table 2 infra - and involves several referential restrictions: contrasts ${ }^{1}$ of entity and polarity, maintenance of the same predication, temporal shifts etc., which induce the narrator to employ a great variety of contrasting and anaphoric means. I shall focus on four information structures (IS: I, II, III and IV), each of which is repeated two or three times during the story, that are shaded in Table 2.

1 A marked change of information is defined as a contrast when it evokes a search for an antecedent utterance that can be compared with respect to the filling of the relevant information unit. In this respect, following Dimroth et al. 2010, we shall adopt the notion of contrast proposed by Umbach (2004), which is based on comparability presupposing both similarity and dissimilarity. 
Patrizia Giuliano: How children "add" or "restrict" entities and temporal spans in

narrations: evidence from Italian and English native children

\begin{tabular}{|c|c|c|c|}
\hline $\mathrm{Nr}^{2}$ & Film segment & $\begin{array}{l}\text { Information Structure } \\
\text { with respect to. antecedent segment }\end{array}$ & $\begin{array}{l}\text { Utterances } \\
\text { with Information } \\
\text { Structure marking } 3\end{array}$ \\
\hline $1-2$ & $\begin{array}{l}\text { Introduction protagonists / } \\
\text { flats }\end{array}$ & & \\
\hline 3 & $\begin{array}{l}\text { Mr. Blue going to bed, } \\
\text { sleeping }\end{array}$ & & \\
\hline 4 & $\begin{array}{l}\text { Mr. Green going to bed, } \\
\text { sleeping }\end{array}$ & $\begin{array}{l}\text { I: Different Time Span, different } \\
\text { Entity, same Polarity, same Predicate } \\
\text { (wrt 03) }\end{array}$ & $\begin{array}{l}\text { Anche il sig. Verdi va a } \\
\text { letto ; } \\
\text { Mr. Green also goes to bed }\end{array}$ \\
\hline 5 & $\begin{array}{l}\text { Mr. Red going to bed, } \\
\text { sleeping }\end{array}$ & $\begin{array}{l}\text { I: Different Time Span, different } \\
\text { Entity, same Polarity, same Predicate } \\
\text { (wrt 03/04) }\end{array}$ & $\begin{array}{l}\text { IL SIG. ROSSI }{ }^{4} \text { va a letto; } \\
\text { MR. RED goes to bed } \\
\text { (or additive particles) }\end{array}$ \\
\hline 6 & Fire on the roof & & \\
\hline 7 & Mr. Green sleeping & $\begin{array}{l}\text { IV: continual Time Spans, same } \\
\text { Entity, same Polaity, same Predicate } \\
\text { (wrt 04) }\end{array}$ & $\begin{array}{l}\text { Il sig. Verdi sta ancora/ } \\
\text { sempre dormendo; } \\
\text { Mr. Green is still sleeping }\end{array}$ \\
\hline 8 & Mr. Red sleeping & $\begin{array}{l}\text { I: different Time Span, different } \\
\text { Entity, same Polarity, same Predicate } \\
\text { (wrt 07); } \\
\text { IV: continual Time Spans, same } \\
\text { Entity, same Polarity, same Predicate } \\
\text { (wrt 05) }\end{array}$ & $\begin{array}{l}\text { I: Il sig. Rossi fa la stessa } \\
\text { cosa; } \\
\text { So does Mr. Red } \\
\text { (or additive particles) } \\
\text { IV: Anche il sig. Rossi sta } \\
\text { ancora dormendo; } \\
\text { Mr. Red is still sleeping as } \\
\text { well }\end{array}$ \\
\hline 9 & Mr. Blue not sleeping & $\begin{array}{l}\text { II: different Time Span, different } \\
\text { Entity, opposite Polarity, same } \\
\text { Predicate (wrt 03/04) }\end{array}$ & $\begin{array}{l}\text { Solo il sig. Blu non dorme; } \\
\text { Only Mr. Blue does not } \\
\text { sleep } \\
\text { (lexical modifiers and } \\
\text { highlighting of polarity are } \\
\text { also possible) }\end{array}$ \\
\hline 11 & Mr. Blue calling fire brigade & & \\
\hline 12 & $\begin{array}{l}\text { Fireman in bathroom, not } \\
\text { answering }\end{array}$ & & \\
\hline 17 & $\begin{array}{l}\text { Mr. Blue calls the fire } \\
\text { brigade }\end{array}$ & $\begin{array}{l}\text { III: different Time Span, same Entity, } \\
\text { same Polarity, same Predicate (wrt 11) }\end{array}$ & $\begin{array}{l}\text { Il sig. Blu chiama di } \\
\text { nuovo/ancora/sempre... i } \\
\text { pompieri; Mr. Blue calls } \\
\text { the fire brigade again }\end{array}$ \\
\hline 18 & Fireman answering the phone & & \\
\hline 22 & Arrival of fire engine & & \\
\hline 24 & $\begin{array}{l}\text { Rescue net: Mr. Green not } \\
\text { jumping }\end{array}$ & & \\
\hline 25 & Mr. Red not jumping & & \\
\hline 26 & Mr. Blue jumping & $\begin{array}{l}\text { II: different Time Span, different } \\
\text { Entity, opposite Polarity, same } \\
\text { Predicate (wrt 24/25) }\end{array}$ & $\begin{array}{l}\text { Il sig. Blu invece SALta; } \\
\text { Mr. Blue on the other hand } \\
\text { DOES JUMP/JUMPs } \\
\text { (the particles only/solo and } \\
\text { lexical modifiers are also }\end{array}$ \\
\hline
\end{tabular}

2 The numbers in this column refer to the chronological segments of the story.

3 The sentences in this column are potential verbalizations suggested by the author.

4 Capital letters mark prosodic prominence.

ISSN 1615-3014 


\begin{tabular}{|l|l|l|l|}
\hline 27-28 & $\begin{array}{l}\text { The firemen try to rescue Mr. } \\
\text { Green and then Mr. Red }\end{array}$ & $\begin{array}{l}\text { III: different Time Span, same Entity, } \\
\text { same Polarity, same Predicate (wrt 24- } \\
25)\end{array}$ & $\begin{array}{l}\text { l pompieri tentano di } \\
\text { il sig. Verdi e il sig. Rossi; } \\
\text { The firemen try to rescue } \\
\text { Mr. Green and Mr. Red } \\
\text { again }\end{array}$ \\
\hline 29 & $\begin{array}{l}\text { Mr. Red does not want to } \\
\text { jump }\end{array}$ & $\begin{array}{l}\text { III or IV: different Time Span(s), } \\
\text { same Entity, same Polarity, same } \\
\text { Predicate (wrt 25) }\end{array}$ & $\begin{array}{l}\text { Il sig. Rossi si rifiuta } \\
\text { ancora/di nuovo di saltare; } \\
\text { Mr. Red still refuses to } \\
\text { jump / refuses to jump } \\
\text { again }\end{array}$ \\
\hline $30-31$ & $\begin{array}{l}\text { One by one, all of them jump } \\
\text { and the happy end }\end{array}$ & & \\
\hline
\end{tabular}

Table 2: The Finite Story.

In what follows I shall comment the hypothetical means and structures by which native Italian and English speakers could mark the information configurations in question.

As to the first information structure (cf. segments 4, 5 and 8 in Table 2), this is, theoretically, the prototypical information structure for setting up a contrast in the domain of entities, since it involves a shift in the domains of the protagonists and time but maintenance of the levels of polarity and predicate. So, considering the types of means available in Italian and English, I expect informants to use additive particles (It. anche, pure; Engl. also, too, as well;) and their negative counterpart (It. neanche, neppure, nemmeno; Engl. Not... either; neither).

(1) a. It.: Il signor Blu va a letto

The Mr. Blue goes to bed

Engl.: Mr. Blue goes to bed

b. It.: Anche il sig. Verdi va a letto; Neanche / neppure / nemmeno il Also the Mr. Green goes to bed; Neither the

sig. Verdi si sveglia

Mr. Green wakes-up

Engl.: Mr. Green also goes to bed; Mr. Green does not wake up either

A second strategy to signal the addition of an entity is the prosodic prominence on the entity:

(2) a. It.: Il signor Blu va a letto

Engl.: Mr. Blue goes to bed

b It.: Il signor VERdi va a letto

Engl.: MR. GREEN goes to bed

It is also possible to employ verbal additive periphrases (It. fare lo stesso: Engl. to do the same):

(3) a. It.: Il signor Blu va a letto

Engl.: Mr. Blue goes to bed 

narrations: evidence from Italian and English native children

\section{b. It.: Il signor Verdi fa lo stesso}

\section{Engl.: Mr. Green does the same}

For the Second Information Structure (cf. segments 9 and 26 in Table 2), speakers have to convey that a situation applying for the first two characters (Mr. Green and Mr. Red) does not apply for the third one (Mr. Blue), therefore we have a change in the entity and time domains, an opposite polarity but the maintenance of the predicate. For this information structure speakers could either mark the contrast on the entity or highlight the change of polarity. If speakers opt for the entity contrast, they can use restrictive particles: It. solo, solamente, soltanto; Engl. only, just. But the exploitation of adversative expressions is also possible (It. invece, in compenso, diversamente da Mr. X etc.: Engl. on the other hand, instead, differently from $M r . X)^{5}$. The case of opposite polarity represents a third possible strategy for the narrators and it can be marked by the pitch accent on the finite verb; nevertheless, the latter is not a preferential strategy in Romance languages.
a. It.: Il signor Verdi continua a dormire
The Mr. Green continues to sleep-INF
Engl.: Mr. Green continues to sleep
b. It.: Anche il signor Rossi continua a dormire
Also the Mr. Red continues to sleep-INF
Engl.: Mr. Red also continues to sleep
c. It.: Solo il signor Blu non dorme / Il signor Blu invece non dorme /
Only the Mr. Blue not sleeps / The Mr. Blue instead not sleeps /

\section{Il signor Blu SI SVEglia}
The Mr. Blue wakes-up

Engl.: Only Mr. Blue does not sleep / Mr. Blue instead does not sleep / Mr. Blue WAKes UP - DOES WAKe up

As far as the Third Information Structure is concerned (segments 17, 27 and 28 in Table 2), in this case one of the protagonists repeats the same action, so we have an iteration of the same event (that we can also describe as an addition of an event of the same type). In Italian, many iterative devices are at the speaker's disposal (di nuovo, nuovamente, ancora, sempre generally when marking habitualness, un'altra volta, ri-verb); in English the prototypical means to mark iteration is the particle again.

a. It.: Il signor Blu chiama $\mathrm{i}$ pompieri

the Mr. Blue calls the firemen

Engl.: Mr. Blue calls the firemen

\footnotetext{
5 The adversative expressions are different from scope particles for several reasons: their domain of influence can be more difficult to identify unless the prosody disambiguates their scope; they cannot appear in absentia, that is to say that the alternatives to which they apply must necessarily be expressed together with the other components of the utterance as in the following interaction:

A: I have a black bag

B: Me too / *me instead
} 
b. It.: Il signor Blu chiama di nuovo / ancora / un'altra volta / richiama The Mr. Blue calls again /*still /*another time /*recalls i pompieri the fire brigadedon

Engl:: Mr. Blue calls the firemen again

The Fourth Information Structure (segments 8 and 29 in Table 2), finally, is concerned with continual time spans - namely an addition of events of the same type -, that can be marked by temporal particles (It. ancora / sempre and Engl. still) or verbal periphrases such as It. continuare a + Infinitive and Engl. continue to do, keep on V-ing:

$$
\begin{array}{ll}
\text { It.: } & \text { Il signor Rossi dorme ancora / continua a dormire } \\
& \text { The Mr. Red sleeps still / continues to sleep.INF }
\end{array}
$$

Engl.: Mr. Red is still sleeping / continues to sleep

On the whole, I considered nine segments of the story, five of which are concerned with temporal quantification (information structures III and IV), two focus on the polarity contrast (Information structure II) and three on the entity contrast (information structure I).

\section{Theoretical framework and research hypothesis}

In the present study I have decided to compare English and Italian speaking children in order to identify the possible similarities and differences by which textual cohesion is built in a Romance language with respect to a Germanic language. By doing so, my work can give a contribution to the debate about restrictive and (temporal and non temporal) additive particles as used in narrations (cf., in particular, Dimroth et al. 2010 and Giuliano 2012c), even though from the perspective of children's acquisition of the mother tongue rather than from that of native adults or adult L2 learners.

As anticipated in the introduction, I shall try to answer the following questions:

$(1 \mathrm{a} / 1 \mathrm{~b})$ at which age do additive and restrictive means appear?

(2) which functions do additive and restrictive quantification strategies carry out in the discourse organization of very young subjects?

(3) what do the acquisitional paths of these forms in children tell us about the cognitive operations by children of the same age learning different languages?

which strategies, among the ones identified, are language-specific?

The answers will take the adult data as a point of comparison to identify what children still have to learn and what they have to modify to match the adult perspective.

From the textual viewpoint, my analysis is based on the Quaestio approach as described by Klein/von Stutterheim $(1989,1991)$, according to which a text is shaped and informationally organized with respect to an unconscious question individuals learn to formulate since early childhood. The prototypical question, or Quaestio, concerned with a narrative text is what happened to the protagonist in time $X$ ?, where the event is the information segment to specify, or focus, and the protagonist and the time span the segments in topic. But the 

narrations: evidence from Italian and English native children

Quaestio is influenced by the formal and conceptual patterns a certain language has available, which explains the possibility for individuals of different native languages to conceive, for the same type of text, relatively different Quaestiones (for instance, What happened to the protagonist and why?, What happened to the protagonist after time X? etc. ${ }^{6}$. In Klein' and von Stutterheim's opinion, the Quaestio guides the speaker's formal and content choices while building the information structure of a text (introduction, maintenance, shifting and reintroduction of referents) ${ }^{7}$, or referential movement. On the whole, this internal question 'dictates' the discourse principles coherence and cohesion are based on.

Now, with respect to my children's data, my purpose is to test the adoption of such an internal model by very young speakers of English and Italian and the way it combines with restrictive and additive cohesion strategies.

\section{The retellings of adult native speakers of Italian and English: what do children have to learn?}

Tables 3 and 4 show the results concerned with the retellings of adult native speakers of Italian and English.

\begin{tabular}{|c|c|c|c|c|c|}
\hline IS I & Means & & IS II & & \\
\hline Time & Adverbs & $\begin{array}{l}\text { Infine 1 } \\
\text { ('finally') }\end{array}$ & Time & Adverbs & $\begin{array}{l}\text { Finalmente, infine } \\
2 \text { ('finally') }\end{array}$ \\
\hline \multirow[t]{3}{*}{ Entity } & $\begin{array}{l}\text { Additive } \\
\text { Particles }\end{array}$ & $\begin{array}{l}\text { Anche, pure } 34 \\
\text { ('also'); } \\
\text { Nemmeno, } \\
\text { neanche } 4 \\
\text { ('neither, not.. } \\
\text { either') }\end{array}$ & \multirow[t]{3}{*}{ Entity } & $\begin{array}{l}\text { Restrictive } \\
\text { Particles }\end{array}$ & Solo 2 ('only') \\
\hline & \multirow[t]{2}{*}{$\begin{array}{l}\text { Verb-anche- } \\
\text { Subject }\end{array}$} & \multirow[t]{2}{*}{1} & & Clefts & $\begin{array}{l}\text { E l'unico che } 3 \text { / il } \\
\text { primo che } 1 \text { ('it's } \\
\text { the only one/the } \\
\text { first who') }\end{array}$ \\
\hline & & & & Adverbs & $\begin{array}{l}\text { Invece ('instead') } \\
11, \text { mentre } 1 \\
\text { ('whereas') }\end{array}$ \\
\hline \multirow[t]{2}{*}{$\begin{array}{l}\text { Same } \\
\text { Predication }\end{array}$} & Anaphoric VP & $\begin{array}{l}\text { Fare la stessa } \\
\text { cosa ('do the } \\
\text { same thing') } 5\end{array}$ & \multirow[t]{2}{*}{ Generic } & \multirow[t]{2}{*}{ Conjunctions } & \multirow[t]{2}{*}{ Però ('but') 1} \\
\hline & Other & $\begin{array}{l}\text { (Cosi) come } 3 \\
\text { ('like') }\end{array}$ & & & \\
\hline Total & & $\begin{array}{l}\text { Additive } \\
\text { Means } 48\end{array}$ & & & $\begin{array}{l}\text { Restrictive } \\
\text { Means } 5^{8}\end{array}$ \\
\hline
\end{tabular}

6 Giuliano / Di Maio (2008) show that different pragmatic ways of conceiving interaction across cultures also influences the selection of linguistic and conceptual preferences.

7 The Quaestio shaping a whole text is said to be global by contrast to an incidental or local Quaestio a speaker can answer during his textual production, and that he can abandon immediately afterwards. So, with respect to our stimulus, a narrator could focus on a protagonist instead of the event, answering by that a local Quaestio such as Who else jumps?

${ }^{8}$ Corresponding to solo 2 and è l'unico che 3. 


\begin{tabular}{|c|c|c|c|c|c|}
\hline IS III & Means & & IS IV & Means & \\
\hline \multirow[t]{2}{*}{ Time } & Adverbs & $\begin{array}{l}\text { di nuovo } 9 \\
\text { ('again'); al } \\
\text { nuovo invito } 3 \\
\text { ('at the new } \\
\text { invitation'); } \\
\text { un'altra volta } 1 \\
\text { ('another time') }\end{array}$ & \multirow[t]{3}{*}{ Time } & Particles & $\begin{array}{l}\text { ancora } 4 \text { ('still') } \\
\text { (Segment 8); } \\
\text { ancora } 4 \text { ('still ou } \\
\text { again?') / ancora } \\
\text { una volta } 1 \text { ('once } \\
\text { again') (Segment } \\
29 \text { ) }\end{array}$ \\
\hline & Verbs & $\begin{array}{l}\text { Ri-verb 17; } \\
\text { *continuare a } 1 \\
\text { ('keep on'); } \\
\text { tornare 2 ('go } \\
\text { back'); insistere } \\
1 \text { ('insist') }\end{array}$ & & \multirow[t]{2}{*}{ Verbs } & \multirow[t]{2}{*}{$\begin{array}{l}\text { Continuare a } \\
\text { ('keep on...') } 11 \\
\text { (segment 8); } 4 \\
\text { (segment 29) }\end{array}$} \\
\hline $\begin{array}{l}\text { Same } \\
\text { Predication }\end{array}$ & Anaphoric VP & $\begin{array}{l}\text { Fare la stessa } \\
\text { cosa ('Do the } \\
\text { same thing') } 1\end{array}$ & & & \\
\hline Total & & $\begin{array}{l}\text { Additive } \\
\text { Temporal } \\
\text { Means } 34 \\
\end{array}$ & & & $\begin{array}{l}\text { Additive } \\
\text { Temporal Means } \\
24 \\
\end{array}$ \\
\hline
\end{tabular}

Table 3: Information Structures I, II, III, IV: adult Italian native speakers.

\begin{tabular}{|c|c|c|c|c|c|}
\hline \multirow[t]{2}{*}{ IS I } & \multicolumn{2}{|l|}{ Means } & \multirow{2}{*}{$\begin{array}{l}\text { IS II } \\
\text { Time }\end{array}$} & \multicolumn{2}{|l|}{ Means } \\
\hline & & & & Adverbs & $\begin{array}{l}\text { This time, } \\
\text { finally } 2\end{array}$ \\
\hline \multirow[t]{2}{*}{ Entity } & $\begin{array}{l}\text { Additive } \\
\text { Particles }\end{array}$ & $\begin{array}{l}\text { Also } 11 \text {, as well } \\
4 \text {, too } 2 \text {, even } 3 \text {, } \\
\text { not...either } 2\end{array}$ & \multirow[t]{2}{*}{ Entity } & Stressed NP & 2 \\
\hline & Stressed NP & 3 & & Clefts & $\begin{array}{l}\text { He's the } \\
\text { brave one } \\
\text { that } 1\end{array}$ \\
\hline \multirow[t]{3}{*}{ Same Predication } & Anaphoric VP & $\begin{array}{l}\text { Do the same } \\
\text { thing } 7\end{array}$ & \multirow[t]{2}{*}{ Polarity } & Adverbs & Actually 1 \\
\hline & \multirow[t]{2}{*}{ Others } & \multirow[t]{2}{*}{ Same for 1} & & Stressed VP & 1 \\
\hline & & & Generic & Conjunctions & $\begin{array}{l}\text { But, however, } \\
\text { though } 3\end{array}$ \\
\hline Total & & $\begin{array}{l}\text { Additive } \\
\text { Means } 36\end{array}$ & & & $\begin{array}{l}\text { No } \\
\text { Restrictive } \\
\text { Means }\end{array}$ \\
\hline IS III & Means & & IS IV & Means & \\
\hline \multirow[t]{2}{*}{ Time } & Adverbs & $\begin{array}{l}\text { Again } 20, \text { still } \ldots \\
\text { not } 1, \text { finally } 1\end{array}$ & \multirow[t]{2}{*}{ Time } & Particles & $\begin{array}{l}\text { Still } 12 \\
\text { (segment 8); } \\
\text { Still } 14 \\
\text { (segment 29) }\end{array}$ \\
\hline & Anaphoric VP & $\begin{array}{l}\text { Another phone } \\
\text { call } 3\end{array}$ & & Verbs & Continue to 1 \\
\hline Total & & $\begin{array}{l}\text { Temporal } \\
\text { Additive } \\
\text { Means } 24\end{array}$ & & & $\begin{array}{l}\text { Temporal } \\
\text { Additive } \\
\text { Means } 27\end{array}$ \\
\hline
\end{tabular}

Table 4: Information Structures I, II, III, IV: adult English native speakers. 

narrations: evidence from Italian and English native children

As we would expect it, the means concerned with temporal quantification are more numerous, which seems obvious since five of the nine segments that I considered in my analysis involve temporal reiteration or continuity (Italian speakers mark 58 contexts out of 100; English speaking informants mark 51 contexts out of 100).

For the First Information Structure, the tables show that:

- both Italian and English adult native speakers copiously mark this information structure by additive particles and only in a minor way by exclusive particles (Engl. not ... either, neither; It. nemmeno, neanche);

- both groups of informants also exploit anaphoric verbs and noun phrases (he does the same, the same for etc.);

- $\quad$ only English native speakers resort to prosody to mark addition, as in examples 7 and 8:

(7) Lauren, English L1, adult

Mr. Green did not wake up // MR. RED did not wake up

(8) Ailish, English L1, adult

Mr. Green slept while the fire became stronger and stronger // MR. RED slept while the fire became stronger and stronger

For reasons linked to their mother tongue flexible syntax, Italian speakers can exploit the verb-subject order to mark the addition of a new entity (with or without an additive particle), but this strategy turns out to be extremely rare in my data and is used with the subjectpronoun lui (1 occ.), that in spoken Italian replaces egli (the written variant):

(9) Nicola, Italian L1, adult

$\mathrm{Si}$ è coricato pure lui

Himself is laid-down too him

'He laid down too'

For the Second Information Structure, where restrictive strategies are theoretically possible, English native speakers never exploit them; as to Italian speakers, they use them by means of two devices: the restrictive particle solo (ex. 10) and a lexical-syntactic strategy of restrictiveness (ex. 11):

(10) Francesco, Italian L1, adult

Solo il signor Blu comincia ad accorgersi di qualcosa di strano

Only the Mr. Blue starts to realize-INF-himself of something of strange

'Only Mr. Blue starts to realize [that there is] something strange'

(11) Antonella Italian L1, adult

Il signor Blu invece è l' unico che: accetta di lanciarsi

The Mr. Blue instead is the only-one who: accepts of launch-INF-himself

'Mr. Blue instead is the only one who accepts to jump' 
As far as the Third Information Structure is concerned, English native narrations are more "monotonous", so to speak, since the prevailing temporal additive device is the particle again; Italian speakers, conversely, can vary, having at their disposal more devices: so they have resort both to the expressions di nuovo/nuovamente ('again') and to the iterative verbal prefix ri-, conversely, they never use ancora. In both groups there are also other less frequent strategies (another phone call, un'altra volta: another time = 'once again' etc.).

For the Fourth Information Structure, finally, English native speakers definitively prefer still to mark it and they never interpret segment 29 as an iterative process (he still refuses to jump instead of he refuses to jump again). For this same Information Structure, Italian speakers continually alternate between the particle ancora and verbal periphrases such as continuare a + infinitive ('keep on V-ing'); furthermore, Italian speakers sometimes clearly interpret segment 29 as an iterative process (rifiuta di nuovo di saltare: 'he refuses to jump again').

To summarize:

- both English and Italian L1 children have to learn specific additive particles for the First, Third and Fourth Information Structures;

- the task appears to be more difficult for Italian children, since the additive particle ancora can quantify both entities and time spans and have both an iterative and a continual reading: in other words, the use of the same items in similar contexts could make the identification of the specific semantics of a particle slower. To make things even more complicated there is the possibility of using the particle sempre with the same temporal values (iterative - generally in habitual contexts - and continual) as described for ancora;

- Italian children also have to learn that restrictive means can be used in order to mark a contrast of actions, as that is the case for the Second Information Structure (someone does something that someone else refuses to do);

- English native children have to learn the frequency preference for a particle such as still instead of verbal periphrases ('keep on, continue to') for continual processes;

- English native children also have to notice the exploitation of prosody to convey the concept of addition in absence of any lexical or syntactic additive means.

\section{The retellings of Italian and English native four-year-old children}

Tables 5 and 6 are concerned with the data of four year old children.

\begin{tabular}{|c|c|c|c|c|c|c|c|c|}
\hline IS I & \multicolumn{2}{|l|}{ Means } & IS III & \multicolumn{2}{|l|}{ Means } & \multicolumn{3}{|c|}{ Means } \\
\hline Time & Adverbs & $\begin{array}{l}\text { (deictic) Un'altra } \\
\text { volta } 3 \text { ('another } \\
\text { time') }\end{array}$ & Time & $\begin{array}{l}\text { Ad- } \\
\text { verbs }\end{array}$ & $\begin{array}{l}\text { Di nuovo } \\
1, \text { ancora } \\
1 \\
\text { ('again') }\end{array}$ & Time & $\begin{array}{l}\text { Part- } \\
\text { icles }\end{array}$ & $\begin{array}{l}\text { Ancora } 2 \\
\text { ('still') } \\
\text { (segment } \\
8 \text { ) }\end{array}$ \\
\hline \multirow[t]{2}{*}{ Entity } & $\begin{array}{l}\text { Additive } \\
\text { Particles }\end{array}$ & $\begin{array}{l}\text { Anche 1; (deictic) } \\
\text { Anche 2; pure } 5 \\
\text { ('also') }\end{array}$ & & & & & & \\
\hline & $\begin{array}{l}\text { Verb- } \\
\text { (anche)- } \\
\text { Subject }\end{array}$ & 3 & & & & & & \\
\hline
\end{tabular}



narrations: evidence from Italian and English native children

\begin{tabular}{|c|c|c|c|c|}
\hline & Others & $\begin{array}{l}\text { Un altro } 1 \text { ('another } \\
\text { one'); tutti dormono } 1 \\
\text { ('everybody sleeps') }\end{array}$ & & \\
\hline \multirow[t]{2}{*}{$\begin{array}{l}\text { Same } \\
\text { Pre- } \\
\text { dication }\end{array}$} & $\begin{array}{l}\text { Ana- } \\
\text { phoric } \\
\text { VP }\end{array}$ & $\begin{array}{l}\text { Fa lo stesso } 1 \text { ('he } \\
\text { does the same'); sono } \\
\text { tutti uguali } 1 \text { ('they're } \\
\text { all the same') }\end{array}$ & & \\
\hline & Others & $\begin{array}{l}\text { Lo stesso } 1 \text { ('the } \\
\text { same') }\end{array}$ & & \\
\hline Total & \multicolumn{2}{|c|}{ Additive means 19 (deictic use 5) } & $\begin{array}{l}\text { Temporal Additive Means } \\
3\end{array}$ & $\begin{array}{l}\text { Temporal Additive Means } \\
2\end{array}$ \\
\hline
\end{tabular}

Table 5: Information structures I, III, IV: Italian 4-year-old children.

\begin{tabular}{|c|c|c|c|c|c|}
\hline IS I & Means & & IS III & Means & \\
\hline Time & Adverbs & Now 1 & Time & Adverbs & $\begin{array}{l}\text { Again 3, (deictic) again 2, } \\
\text { (deictic) too } 2\end{array}$ \\
\hline \multirow[t]{3}{*}{ Entity } & \multicolumn{2}{|c|}{ Stressed NP } & & & \\
\hline & $\begin{array}{l}\text { Additive } \\
\text { Particles }\end{array}$ & Too 4 & & & \\
\hline & Others & $\begin{array}{l}\text { The other } \\
\text { one } 3\end{array}$ & & & \\
\hline $\begin{array}{l}\text { Same } \\
\text { Predication }\end{array}$ & \multicolumn{2}{|c|}{ Anaphoric VP } & & & \\
\hline Total & & $\begin{array}{l}\text { Additive } \\
\text { Means } 7\end{array}$ & & & $\begin{array}{l}\text { Temporal additive } \\
\text { means } 5 \text { (deictic use 2) }\end{array}$ \\
\hline
\end{tabular}

Table 6: Information Structures I, III: 4-year-old English native children.

The Second Configuration is never marked either by Italian or English 4-year-old children. As to the First and Third Information Structures, some of the attempts to express the repetition of the same action by two different characters or the same character are given by examples 1214 (the symbol // marks the passage to a different scene of the story; three full stops indicates the suppression of a passage):

(12) Ofek, English L1, 4-year-old, First Information Structure

He goes to sleep // he go to sleep too // he go to sleep too

(13) Alessandra, Italian L1, 4-year-old, 1rst Information Structure

Dorme // pure lui dorme // pure lui dorme

Sleeps // also him sleeps // also him sleeps

'He sleeps // he also sleeps // he also sleeps'

(14) Ashley, English L1, 4-year-old, Third Information Structure

He's on the telephone... // He's on the phone again

(15) Francesca, Italian L1, 4-year-old, $3^{\text {rd }}$ Information Structure

Ha finito di telefonare... // sta telefonando di nuovo

Has finished to call.INF... // is calling again 
'He has finished to call... // he is calling again'

Despite the correctness of the additive means in the passages that we have just seen, the retellings of the 4-year-olds can also be very ambiguous, as in example 16:

(16) Désirée, Italian L1, 4-year-old, First Information Structure

Il bambino che stava a letto e ha spento la luce...//

The child that was at bed and has switched.off the light

'The child that was in bed and switched the light off [referred to Mr. Red]'

È andato a letto e il bambino ha spento un' altra volta la luce //

Is gone at bed and the child has switched.off an other time the light

'He went to bed and switched the light off again [referred to Mr. Green] '

Tutti sono uguali // È andato a letto a spegnere la luce anche...//

All-PL are equal // is gone to bed to switch.off the light also [...]//

'All of them are equal // he went to bed to switch the light off too [referred to Mr. Red]'

E: ha fatto un rumore //

E: has made a noise //

'E: he made a noise [the scene where Mr. Green keeps on sleeping] //

Ha fatto un rumore anche

Has done a noise also

'Has made a noise too [the scene where Mr. Red keeps on sleeping]'

Despite the clear attempts to mark anaphoric links, the Italian passage shows strong failures both for the lexical selection of some items and for their position in the syntactic chain. In the second line, the expression un'altra volta ('another time = again') could prompt us to think that the young informant has not grasped the change in the entity domain; but, immediately afterwards, she adds, with respect to the three protagonists, that tutti sono uguali ('all of them are equal'), which shows her being conscious as to the existence of three different characters. The source of the mistake could lie not in the lexical choice but rather in the fact that the subject confuses the intratextual relations with deictic relations: so un'altra volta is referred to the repetition of a scene similar to one she has already watched, and consequently to the stimulus rather than to the action of a specific protagonist. As to the last utterance: $h a$ fatto un rumore anche ('has made a noise too'), here the scope of anche (indicated by the underlining) is once again deictic (= anche in questa scena si è sentito un rumore: 'in this scene too you heard a noise'). For this sentence you have to notice the position of anche at the end of the sentence, which puzzles the listener, since anche cannot normally be placed in this position (except in very rare and pragmatically very marked contexts). The placement of anche at the end of the utterance also appears in è andato a letto a spegnere la luce anche ('[he = Mr. Red] went to bed to switch the light off too'), where the final position prevents us from deciding whether anche scopes over the implicit subject (intratextual interpretation) or 

narrations: evidence from Italian and English native children

over the stimulus (deictic interpretation): in both interpretations the demanded syntax in Italian would be 'anche $+\underline{\mathrm{Mr} . \mathrm{X} / \mathrm{In} \text { this scene }}+\mathrm{VP}$ '.

Let's look at some other Italian and English examples:

(17) Francesca, Italian L1, 4-year-old, outside the Information Structures considered

Ha chiuso la porta // Sta telefonando di nuovo // Anche questo sta telefonando

Has closed the door// is telephoning again // also this is phoning

'He closed the door // he [Mr. Blue] is phoning again // This too is phoning [referred to the fireman who answers the phone]'

(18) Rosalinda, English L1, 4-year-old, First Information Structure

There was two fires [the fire spreads out] // there was fire on his house too [Mr. Green wakes up and is scared] // there's fire too [Mr. Red wakes up and is scared as well]

(19) Finni, English L1, 4-year-old, outside the Information Structures considered

He's speaking on the telephone [referred to Mr. Blue] // on the telephone again [referred to the fireman who answers the phone]

(20) Penelope, English L1, 4-year-old, First Information Structure

$\mathrm{He}$ is in the dark because it's night time // it's night time again // and then night time again

The young narrators, similarly to the author of example 16, highlight the similarity of two scenes instead of the logical relationship between them with respect to the story plot. For examples 17 and 18, children are establishing an external comparison between three similar scenes; in passages 19 and 20 the comparison is with respect to someone on a telephone, so the anaphoric linkage that It. anche and Engl. again mark is external to the plot of the story and refers to the fact that a scene where someone is on a phone shows up twice.

It can be interesting to remark that the only additive particle scoping on entities, appearing in the 4-year-old data of English L1 children, is the particle too, even outside the information structures that I considered, maybe because of the more perceptible position that this additive item demands, namely the end of the utterance; as a matter of fact, the final syntactic position of too causes no troubles to very young children.

A further remark can be noticed for the 4-year-old groups: the expressions the other one / another one and their Italian equivalents can function as additive strategy:

(21) Ashley, English L1, 4-year-old, 1rst Information Structure

He go to sleep [referred to Mr. Blue] // and the other one go to sleep [referred to Mr. Green] // the other one go to sleep [referred to Mr. Red]

(22) Pasquale, Italian L1, 4-year-old, 1rst Information Structure

Uno che dorme sul letto //

One who sleeps on-the bed //

'someone who sleeps on the bed' // 
Un altro che dorme sul letto

A other who sleeps on-the bed

'Another one who sleeps on the bed'

To summarize, 4-year-old subjects:

- in general, are not capable of organising what they say in a holistic narration;

- tend to confuse the intratextual relations with deictic relations whatever the mother tongue they are learning;

- can have troubles with the positioning of some additive particles (Italian children) or if possible - they avoid the particles requiring an internal positioning (English L1 children);

- have more problems with temporal quantification than with the quantification of entities (scarce frequency of temporal means in Italian and deictic use of temporal means in English);

- the Second Information Structure is never marked by any child of the two groups whereas the Fourth Information Structure shows up in just the Italian narrations.

The first two Points have certainly a relationship since progressively the very young child will select and link the right position to the right scope (cf. par. 6 and 7).

\section{The retellings of Italian and English L1 7-year-old-children}

Tables 7 and 8 are concerned with Italian and English L1 children.

\begin{tabular}{|c|c|c|c|c|c|}
\hline IS I & Means & & IS II & Means & \\
\hline \multirow[t]{2}{*}{ Time } & Adverbs & $\begin{array}{l}\text { (deictic) Un'altra } \\
\text { volta } 2 \text { ('again') }\end{array}$ & \multirow[t]{2}{*}{ Time } & \multirow[t]{2}{*}{ Adverbs } & \multirow[t]{2}{*}{ Poi 1 ('then') } \\
\hline & Particles & $\begin{array}{l}\text { (deictic) Ancora } 2 \\
\text { ('still'); * sempre } 1 \\
\text { ('always') }\end{array}$ & & & \\
\hline \multirow[t]{4}{*}{ Entity } & Stressed NP & $\begin{array}{l}\text { Il Signor ROsso } 1 \\
\text { ('Mr. RED') }\end{array}$ & \multirow[t]{4}{*}{ Entity } & \multirow[t]{2}{*}{$\begin{array}{l}\text { Restrictive } \\
\text { Particles }\end{array}$} & \multirow[t]{2}{*}{ Solo 1 ('only') } \\
\hline & $\begin{array}{l}\text { Additive/ } \\
\text { Exclusive } \\
\text { Particles }\end{array}$ & $\begin{array}{l}\text { Anche } 7, \text { pure } 4 \\
\text { ('also'); } \\
\text { manco 1, nemmeno } 1 \\
\text { ('neither') }\end{array}$ & & & \\
\hline & $\begin{array}{l}\text { Verb- } \\
\text { anche- } \\
\text { Subject }\end{array}$ & 2 & & \multirow[t]{2}{*}{ Adverbs } & \multirow[t]{2}{*}{ Invece 7 ('instead') } \\
\hline & Others & Un altro 1 ('another') & & & \\
\hline $\begin{array}{l}\text { Same } \\
\text { Predication }\end{array}$ & $\begin{array}{l}\text { Anaphoric } \\
\text { VP }\end{array}$ & $\begin{array}{l}\text { (deictic) E' lo stesso } \\
1 \text { ('it's the same'), } \\
\text { stessa cosa } 1 \text { ('same } \\
\text { thing') }\end{array}$ & Polarity & Adverbs & Sì 1 ('yes') \\
\hline Total & & $\begin{array}{l}\text { Additive Means } 22 \\
\text { (deictic use 5) }\end{array}$ & & & Restrictive Means 1 \\
\hline
\end{tabular}



narrations: evidence from Italian and English native children

\begin{tabular}{|c|c|c|c|c|c|}
\hline IS III & Means & & IS IV & Means & \\
\hline \multirow[t]{3}{*}{ Time } & Particles & $\begin{array}{l}\text { Ancora } 4 \text { ('again'); } \\
\text { *un altro poco ('a bit } \\
\text { more') }\end{array}$ & \multirow[t]{3}{*}{ Time } & Particles & $\begin{array}{l}\text { ancora } 3, \text { sempre } 1 \\
\text { (Segment } 8) \text { ('still'); } \\
\text { ancora } 1, \text { sempre } 1 \\
\text { (Segment 29) ('still ou } \\
\text { again? '); di nuovo (1) }\end{array}$ \\
\hline & Verbs & $R i$-verb 4 ; insistere 1 & & Verbs & $\begin{array}{l}\text { Continuare a ('keep } \\
\text { on') } 1 \text { (segment } 8)\end{array}$ \\
\hline & & & & $\begin{array}{l}\text { VP } \\
\text { Repetition }\end{array}$ & $\begin{array}{l}\text { Diceva no diceva no } 1 \\
\text { ('he said no') (segment } \\
29 \text { ) }\end{array}$ \\
\hline Total & & $\begin{array}{l}\text { Temporal Additive } \\
\text { Means } 9\end{array}$ & & & $\begin{array}{l}\text { Temporal Additive } \\
\text { Means } 8\end{array}$ \\
\hline
\end{tabular}

Table 7: Information structures I, II, III, IV: Italian 7-year-old children.

\begin{tabular}{|c|c|c|c|c|c|}
\hline IS I & Means & & IS II & Means & \\
\hline Time & Adverbs & Then 1 , now 1 & Time & Adverbs & Finally 1 \\
\hline Entity & $\begin{array}{l}\text { Additive } \\
\text { Particles }\end{array}$ & Too 5, as well 1 & \multirow[t]{2}{*}{$\begin{array}{l}\text { Generic } \\
\text { Means }\end{array}$} & & \multirow[t]{2}{*}{1} \\
\hline $\begin{array}{l}\text { Same } \\
\text { Predication }\end{array}$ & $\begin{array}{l}\text { Anaphoric } \\
\text { VP }\end{array}$ & 1 & & & \\
\hline Total & & Additive Means 7 & & & No Restrictive Means \\
\hline IS III & Means & & IS IV & Means & \\
\hline Time & Particles & Again 4, always 1 & Time & Particles & $\begin{array}{l}\text { Still } 2 \text { (segment 8); } \\
\text { Still } 3 \text { (segment 29) }\end{array}$ \\
\hline Total & & $\begin{array}{l}\text { Temporal Additive } \\
\text { Means } 5\end{array}$ & & & $\begin{array}{l}\text { Temporal Additive } \\
\text { Means } 5\end{array}$ \\
\hline
\end{tabular}

Table 8: Information structures I, II, III, IV: 7-year-old English native children.

As far as Italian 7-year-old children's retellings are concerned, we still find, for the First and Third Information Structures, some problems with occurrences of additive means such as It. un'altra volta, ancora, sempre in contexts involving iteration.

(23) Benedetta, Italian L1, 7-year-old, 1st Information Structure

Nella casetta verde sta facendo una musica che lo sta facendo spaventare // In-the house-DIM green is doing a music that him is making scare-INF // 'In the little green house there's music which is scaring him //'

Nella casetta rossa sta facendo un'altra musica uguale a quell'altra In-the house-DIM red is doing a other music equal to that other 'In the little red house there's some other music equal to the other one'

Che lo sta facendo ancora spaventare That him is making still scare-INF

'Which is still scaring him' 
(24) Rossella, Italian L1, 7-year-old, $1^{\text {st }}$ Information Structure

Il signor Rosso si è messo sopra al letto //

The Mr. Red himself is put on at-the bed //

'Mr. Red lied down on the bed' //

Il signor Verde si è steso * sempre $^{9}$ sopra al letto

The Mr. Green himself is lied.down *always on at-the bed

'Mr. Green also lied down on the bed'

For examples (23) and (24) it is difficult to decide whether the informants use ancora and sempre in a deictic way or, alternatively, they have problems with the functional and discourse peculiarities of these means, namely with the fact that: ancora and sempre refer to the iteration or continuation of an action by the same character. The polyfunctional semantics of It. ancora (= some more, again, still) and sempre (= still, again) could, at least partly, explain the ambiguities found in the retellings in question.

Still for Italian children, the most striking difference between the 7-year-old and the 4-yearold subjects lies in the emergence of markings for the Second Information Structure, and among these devices the restrictive particle only.

(25) Camilla, Italian L1, 7-year-old, 2nd Information Structure

Solo quello Blu si è svegliato

Only that Blue himself is woken up

'Only the Blue one woke up'

Outside the information structures that I analysed, I also found the construction è l'unico che... ([he] is the only one who...'), which together with the restrictive particle solo ('only') actualize the uniqueness strategy, appearing in Italian adults' retellings (cf. § 4).

Concerning the Third Information Structure, the Italian 7-year-old group exploits varied means such as the verbal prefix ri-; a semantic lexical strategy such as the use of the anaphoric verb insistere also shows up.

As to the use of prosodic means, I identified, for the First Information Structure, a prosodic stress on signor ROsso replacing a lexical marking such as anche:

(26) Giacomo, Italian L1, 7-year-old, 1st Information Structure

Poi il signor ROSso e: va a letto spegne la luce si mette le coperte Then the Mr. RED e: goes to bed switches.off the light himself puts the covers

e va a dormire

and goes to sleep-INF

'Then Mr. RED e: goes to bed he turns the light off he covers himself and goes to sleep'

9 Here the use of sempre is not grammatical since the continual reading is referred to a character different from Mr. Red in the first sentence. 

narrations: evidence from Italian and English native children

This prosodic device never appears in Italian adult retellings and otherwise it is exceptional in children's narrations of any age as well, and for this reason I consider it as an occasional childish strategy.

Concerning the English L1 7-year-olds, the following observations apply:

- the deictic use of again as additive particle referred to the stimulus disappears;

- a new expression to add entities shows up, that is to say as well;

- similarly to the younger 4-year-old group, the 7-year-olds never exploit restrictive particles to mark the Second Information Structure;

- no prosodic stress on NP is exploited to mark the addition of entity involved by the First Information Structure.

With respect to the Italian children of the same age, English L1 7-year-olds show no significant problem with the expression of iteration, except for example 27 below, in which we find a use of the temporal particle always comparable to It. sempre in example 24 , since always - as used by the child - refers to the iteration of an action by a different character with respect to the previous scene, which is inappropriate because always presupposes the same agent.

Adrian, English L1, 7-year-old

He laid on his bed and then he had a moustache on his face [referred to Mr. Green who sits up in his bed] // *Always standing up and he had a beard on his face [referred to Mr. Red]

To summarize:

on the whole, seven-year-old children's retellings show several additive and restrictive cohesive elements (inside and outside the information structures that I considered), some of which never appear in the younger group: so for the English group, we find still and as well; for the Italian group, we have, sempre ('always, still'), the iterative verb prefix ri-, the restrictive particle solo ('only') and the exclusive particles nemmeno, manco ('neither'). In other words, the narrations of the seven-year-olds show a perspective which is already very close to that of the adult group of the specific language.

\section{The retellings of Italian and English 10-year-old children}

As emerges from tables 9 and 10, by the age of ten we observe a continued progression for the four information structures in question.

\begin{tabular}{|c|c|c|c|c|c|}
\hline IS I & Means & & IS II & Mean & \\
\hline Time & Adverbs & $\begin{array}{l}\text { *Ancora } 1 \text { ('more } \\
\text { and more') }\end{array}$ & Time & Adverbs & $\begin{array}{l}\text { A questo punto } 1 \text { ('at this } \\
\text { point') }\end{array}$ \\
\hline \multirow[t]{3}{*}{ Entity } & $\begin{array}{l}\text { Additive } \\
\text { Particles }\end{array}$ & $\begin{array}{l}\text { Anche 31, pure: } 7 \\
\text { ('also'); nemmeno: } 1 \\
\text { ('neither') }\end{array}$ & \multirow[t]{3}{*}{ Entity } & $\begin{array}{l}\text { Restrictive } \\
\text { Particles }\end{array}$ & Solo 1 ('only') \\
\hline & \multirow[t]{2}{*}{$\begin{array}{l}\text { Verb- } \\
\text { Subject }\end{array}$} & \multirow[t]{2}{*}{2} & & Adverbs & Invece 10 ('instead') \\
\hline & & & & Others & Per primo 1 ('as first') \\
\hline $\begin{array}{l}\text { Same } \\
\text { Predication }\end{array}$ & $\begin{array}{l}\text { Anaphoric } \\
\text { VP }\end{array}$ & $\begin{array}{l}\text { Fare /succedere lo } \\
\text { stesso } 6 \text { ('do / happen } \\
\text { the same') }\end{array}$ & Generic & Conjunctions & Però / ma 4 ('but') \\
\hline
\end{tabular}




\begin{tabular}{|c|c|c|c|c|c|}
\hline & Others & $\begin{array}{l}\text { Stessa cosa / lo } \\
\text { stesso } 5 \text { ('same thing } \\
\text { / the same') }\end{array}$ & & & \\
\hline Total & & Additive means 55 & & & Restrictive Means 1 \\
\hline IS III & Means & & IS IV & Means & \\
\hline \multirow[t]{2}{*}{ Time } & Adverbs & $\begin{array}{l}\text { Un'altra volta } 1 \\
\text { ('another time'); di } \\
\text { nuovo } 6 \text { ('again'); al } \\
\text { terzo invito } 1 \text { (at the } \\
\text { 3rd invitation'); un } \\
\text { altro po' } 1 \text { ('a bit } \\
\text { more'); sempre 1, } \\
\text { ancora } 1 \text { ('still') }\end{array}$ & \multirow[t]{2}{*}{ Time } & Particles & $\begin{array}{l}\text { Ancora } 2 \text { (Segment 8) } \\
\text { ('still'); } \\
\text { ancora 5, sempre } 2 \text { ('still } \\
\text { or again'?) (Segment 29) }\end{array}$ \\
\hline & Verbs & $\begin{array}{l}R i \text {-verb 7; insistere } 4 \\
\text { ('insist'), }\end{array}$ & & Verbs & $\begin{array}{l}\text { Continuare a ('keep on') } 1 \\
\text { (segment } 8 \text { ) }\end{array}$ \\
\hline Total & & $\begin{array}{l}\text { Temporal Additive } \\
\text { Means } 21\end{array}$ & & & $\begin{array}{l}\text { Temporal Additive } \\
\text { Means } 10\end{array}$ \\
\hline
\end{tabular}

Table 9: Information structures I, II, III, IV: Italian 10-year-old children.

\begin{tabular}{|c|c|c|c|c|c|}
\hline IS I & Means & & IS II & Means & \\
\hline Time & Adverbs & Now 1 & & & \\
\hline Entity & $\begin{array}{l}\text { Additive } \\
\text { particles }\end{array}$ & $\begin{array}{l}\text { Also } 4 ; \text { too } 1 \text {; as well } \\
1 \\
\text { Not... either } 1 \text {; } \\
\text { neither } 1\end{array}$ & & & \\
\hline \multirow[t]{2}{*}{$\begin{array}{l}\text { Same } \\
\text { Predication }\end{array}$} & $\begin{array}{l}\text { Anaphoric } \\
\text { VP }\end{array}$ & Do the same thing 2; & \multirow{2}{*}{$\begin{array}{l}\text { Polarity } \\
\text { Generic }\end{array}$} & Particles & \multirow{2}{*}{$\begin{array}{l}\text { Just } 1 \\
\text { But } 1\end{array}$} \\
\hline & Others & The same thing 2 & & Conjunctions & \\
\hline Total & & Additive Means 12 & \multicolumn{3}{|r|}{ No Restrictive Means } \\
\hline IS III & Means & & IS IV & Means & \\
\hline \multirow[t]{2}{*}{ Time } & Adverbs & Again 3 & \multirow[t]{2}{*}{ Time } & \multirow[t]{2}{*}{ Particles } & \multirow[t]{2}{*}{$\begin{array}{l}\text { Still } 1 \text { (segment 8); Still } 5 \\
\text { (segment 29) }\end{array}$} \\
\hline & Verbs & Retry 1 & & & \\
\hline Total & & $\begin{array}{l}\text { Temporal Additive } \\
\text { Means } 4\end{array}$ & & & $\begin{array}{l}\text { Temporal Additive } \\
\text { Means } 6\end{array}$ \\
\hline
\end{tabular}

Table 10: Information structures I, II, III, IV: 10-year-old English native children.

For Italian children, this progression is concerned with the frequency of the means that tenyear-old children use rather than with their variety. Problems with iterative means such as sempre and ancora have disappeared.

For English native children, the progression observed by ten involves the typology of additive means rather than their quantity, since we find the particle also - which is completely lacking in the other age groups, even outside the information structures considered -, the exclusive expressions not... either and neither and the iterative re-Verb strategy (retry), an uncommon strategy in English. Still for the English L1 group, the inappropriate use of always has disappeared.

From a global viewpoint, the retellings of the 10-year-old groups are very cohesive and well integrated into a holistic perspective of the proposed narrative task. But what do children aged 

narrations: evidence from Italian and English native children

of ten still have to learn with respect to adults? As for the Italian ten-year-old children, the comparison with adults' retellings of The Finite Story demonstrates a great analogy between the means that the latter employ and those exploited by children. Nevertheless, the temporal additive means are less exploited than the additive means concerning the contrast of entities, whereas the opposite is true for adults (adults: 58 occ. s out of the 100 possible markings; ten-year-old children: 31 out of 100; 20 interviews for both groups). Let's not forget that for temporal quantification I considered five segments but just three for entity additive quantification. The unbalance in the use of temporal additive means is also valid for the comparison between adult English native speakers and ten-year-old children, even considering that for children I have just 10 interviews (adults 52 occ. s out of 100; ten-yearold children: 10 occ. s out of 50).

Still for the English L1 group, they show no sensitiveness for the use of prosody to mark addition (First Information Structure); more data is certainly needed, but we can remark the low frequency of this strategy in the adult reference group as well.

\section{Back to the research questions}

In what follows I shall discuss the research questions presented in par. 7 and try to interpret my results by the perspective of the Quaestio theory.

(1a) At which age do additive means appear?

(3) What do the acquisitional paths of these forms in children tell us about the cognitive operations by children of the same age learning different languages?

According to the ages that I considered and to the task that I used, additive means appear from the age of four on but with some differences according to the types of quantification solicited, namely the quantification of entities ( 3 segments in the story) and that of time spans (5 segments in the story):

- Italian L1 children of any age, but particularly the 4-year-olds, clearly have less problems in quantifying entities rather than time spans;

- English L1 children show a greater balance between entity and temporal quantification but, at four, most of the temporal additive means have a deictic meaning;

- with respect to adult reference groups, Italian and English L1 children of any group exploit additive temporal means less frequently than means quantifying entities;

- the quantification of entities involving a negation (exclusive particles: It. neanche, nemmeno, neppure, manco; Engl not ... either, nor... neither) shows up from the age of seven on for Italian and from the age of ten on for English.

Now, these results push me to hypothesize an acquisitional path such as the one illustrated in Scheme 1:

\section{Scheme 1. Acquisitional path at the conceptual level}

Addition of entity (entity contrast: also) > addition of time span (temporal contrast: again, still) > exclusion of an entity (entity contrast: $n e i t h e r)$ 
Contrasts focusing on the addition of an entity (cf. the First Information Structure) appear in a precocious way; contrasts focusing on the addition of different time spans by the same character (cf. the Third and Fourth Information Structures) show up more slowly; the concept of exclusion (negative addition) shows up even later.

The results summarized by scheme 1 turn out to be valid for another experiment (created by C. Dimroth, Mr. Blue and Mr. Red Story) that I tested just on Italian children (cf. Giuliano 2012a). This second task consists of several pictures in which two different characters do the same thing, or one character keeps on doing the same action for a period of time or repeats an action after some time. This experiment was also tested by Benazzo et al. (2004) on French, German and Polish children and they also ascertained that the addition of entity is marked in a more precocious way than temporal iteration or continuity. From a cognitive viewpoint, the precocious emergence of entity contrasts by additive means is in agreement with what Givón (1995: 380) maintains with respect to nominal referents: they are perceptually and cognitively more salient, they are acquired early in ontogeny and evolve early in phylogeny, they are culturally central entities, in particular those that are subject-agent (human, active, conscious, wilful) or object-patient (concrete, compact, usable). As to negative particles, their later appearance is in agreement with some studies about negation showing the more problematic processing of negative structures by children with respect to the positive ones (cf. Giuliano 2004 for an overview of the several works). So I hypothesize that scheme 1 has to do with age cognitive restrictions independently from the $L 1$ the child is learning.

(1b) at which age do restrictive means appear?

(2) which functions do additive and restrictive quantification strategies carry out in discourse organization of very young subjects?

As for means concerning the addition of entity or time spans (also, too...; anche, pure...; again...; di nuovo), very young children tend to use them with a deictic/extra-textual function, in other words they confuse the plot line of the story and the succession of videoclips or pictures by which the story itself is furnished. This functioning of additive means in the narrative task proposed progressively disappears from the age of seven in agreement with the progressive dismissal of the egocentric perspective typical of the very young child. At this point children can make additive contrasts by using scope expressions in the appropriate way, a consideration valid both for the acquisition of English and Italian.

As far as the restrictive means are concerned, in the retellings of The Finite Story task, they have a secondary role in the narrations of Italian children from the age of seven on and no role in the retellings of English L1 children. Nevertheless, this result can depend on the features of The Finite Story stimulus; as a matter of fact, the Second Information Structure involves several strategies to contrast different actions of different characters and not necessarily restrictive devices, but whereas in English they are never used, in Italian they show up. So the emergence of solo ('only') and è l'unico che ('he's the only one who') in Italian 7 and 10-yearold children's narrations for the Second Information Structure could be due to specific strategies of building textual cohesion in their mother tongue as otherwise some other studies using The Finite Story as experimental test seem to confirm (cf. Dimroth et al. 2010; Giuliano 2012c). 

narrations: evidence from Italian and English native children

(4) Which strategies, among the ones identified in children's retellings, are language-specific?

- the exploitation of restrictive means for the Second Information Structure by Italian children from the age of seven on is an Italian specific cohesion strategy;

- the more frequent problems that Italian children have with the concept of iteration with respect to English L1 children could be due to the polyfunctional semantics of the Italian particles ancora ('more, again, still') and sempre ('always, again, still');

- the late appearance of also in English L2 children's data, an internal positioning particle, is probably caused by the fact that English has an external, perceptually more salient particle, namely too, whose semantics is equal to that of also.

From the perspective of the Quaestio theory that I have adopted (cf. par. 3), my data let me interpret the results obtained for The Finite Story task in the following way: in terms of textual organisation, four-year-old children are not capable of planning a global narrative perspective such as the one intervening when the Quaestio principle has definitively been elaborated by the cognitive system. This perspective is just "sketched", so to speak, and it matches the concept of script proposed by Fayol (1985), by which the author refers to a banal sequence of actions with no hierarchical organization and purpose, which explains the incomplete and referentially ambiguous character of utterances but also the incompleteness of the retellings altogether. This result could partly be due to children's inability to select the conceptual domains pertinent for the Quaestio a certain task requires, which justifies fouryear-old children's dispersion of attention and their focus on details of little or no importance for the dynamics of the story. Between the ages of 7 and 10, my results show the increasing ability of Italian and English speaking children with the conceptual and linguistic specificities the task in question demands in their mother tongue, namely their aptitude to contrast entities, actions and temporal spans in agreement with the increasing holistic planning of a narrative text. (cf. the concepts of plan and schema by Fayol 1985).

\section{References}

Andorno, Cecilia (2005): "Additive and restrictive particles in Italian as a second language. Embedding in the verbal utterance structure". In: Hendriks, Henriette (ed.): The Structure of Learner Variety. Berlin, Mouton de Gruyter: 405-444.

Benazzo, Sandra (2003): "The interaction between the development of verb morphology and the acquisition of temporal adverbs of contrast: a longitudinal study in French, English and German L2". In: Dimroth, Christine/Starren, Marianne (eds.): Information Structure and the Dynamics of Language Acquisition. Amsterdam, John Benjamins: 187210.

Benazzo, Sandra et al. (2004): "Le rôle des particules additives dans la construction de la cohésion discursive en langue maternelle et en langue étrangère". Langages 155: 76-104.

Dimroth, Christine (2002): "Topics, assertions, and additive words: how L2 learners get from information structure to target-language syntax". Linguistics 40/4: 891-923.

Dimroth, Christine (2006): The Finite Story, Max-Planck-Institute for Psycholinguistics, http://corpus1.mpi.nl/ds/imdi_browser?openpath=MPI560350\%23, accessed April 28, 2015.

Dimroth, Christine (2009): "Stepping stones and stumbling blocks. Why negation accelerates and additive particles delay the acquisition of finiteness in German". In: Dimroth, 
Christine/Jordens, Peter (eds.): Functional Categories in Learner Language. Berlin/New York, De Gruyter: 137-170.

Dimroth, Christine et al. (2010): "Given claims about new topics. The distribution of contrastive and mantained information in Romance and Germanic languages". Journal of pragmatics 42: 3328-3344.

Fayol, Michel (1985): Le Récit et Sa Construction. Une Approche de Psychologie Cognitive. Neuchâtel/Paris: Delachaux \& Niestlé Editeurs.

Giuliano, Patrizia (2004): La Négation Linguistique dans l'Acquisition d'une Langue Etrangère. Un débat Conclu? Bern: Peter Lang.

Giuliano, Patrizia (2012a): "Discourse Cohesion in Narrative Texts: The Role of Additive Means in Italian L1 and L2". In: Watorek, Marzena/Benazzo, Sandra/Hickmann, Maya (eds.): Comparative Perspectives on Language Acquisition: A tribute to Clive Perdue. Bristol (UK), Multilingual Matters: 375-400.

Giuliano, Patrizia (2012b): "The construction of textual cohesion in narrative texts: evidence from different tasks by Italian children from 4 to 10 years old". Linguistica e Filologia 32: $7-49$.

Giuliano, Patrizia (2012c): "Contrasted and maintained information in a narrative task: analysis of texts in English and Italian as L1s and L2s". EUROSLA Yearbook 2012, 12: $30-62$.

Giuliano, Patrizia/Di Maio, Luca (2008): "Abilità descrittiva e coesione testuale in L1 e L2: lingue romanze e lingue germaniche a confronto". Linguistica e filologia 25: 125-205.

Givón, Talmy (2009): The Genesis of Syntactic Complexity. Amsterdam/Philadelphia: John Benjamins.

Klein, Wolfgang/Stutterheim, Christiane von (1989): "Referential movement in descriptive and narrative discourse". In: Dietrich, Reiner/Gramann, Carl F. (eds): Language Processing in Social Context. Amsterdam, Elsevier Science Publishers B. V: 39-76.

Klein, Wolfgang/Stutterheim, Christiane von (1991): "Text structure and referential movement". Sprache und Pragmatik, 22: 1-32.

Watorek, Marzena/Dimroth, Christine (2005): "Additive scope particles in advanced learner and native speaker discourse". In: Hendriks, Henriette (ed.): The Structure of Learner Variety. Berlin, Mouton de Gruyter: 445-488. 